\title{
ANALISIS KANDUNGAN ASAM LEMAK OMEGA 3, OMEGA 6 DAN OMEGA 9 DARI IKAN LELE (Clarias sp) PADA PENINGKATAN NUTRISI BALITA
}

\author{
Nurasmi $^{1}$, Agus Purnama Sari ${ }^{2}$, Rusmiati $^{3}$ \\ 1,2\&3, Prodi Kebidanan, Fakultas Ilmu Kesehatan, Universitas Borneo Tarakan \\ *Email:asmiyuri2@gmail.com
}

\begin{abstract}
Abstrak
Asam lemak omega-3, omega-6 dan omega-9 merupakan asam lemak esensial yang diperlukan oleh janin dan bayi untuk perkembangan otak dan daya tahan tubuh terhadap penyakit serta perkembangan indra penglihatan dan sistem kekebalan tubuh bayi dan balita. Asam lemak omega-3, omega-6 dan omega-9 banyak terdapat pada ikan laut seperti tuna, salmon, sardine dan tenggiri. Namun, ikan-ikan tersebut memiliki nilai ekonomi yang tinggi, untuk itu diperlukan sumber Asam lemak omega-3, omega-6 dan omega-9 yang relatif lebih murah dan mudah didapatkan. Salah satu jenis ikan yang memiliki harga relatif murah dan mudah didapatkan adalah ikan lele (Clarias sp). Tujuan penelitian ini adalah untuk untuk menganalisis potensi asam lemak omega-3, omega-6 dan omega-9 dari daging ikan Nomei di Kota Tarakan. Metode yang digunakan dalam penelitian ini HPLC (high performance liquid chromatography). Hasil penelitian menunjukkan bahwa kandungan ikan lele mengandung asam lemak omega-3 29,9 g/100 gr, asam lemak omega-6 5,5 gr/100gr dan asam lemak omega-9 9,9 gr/100gr. Kandungan tertinggi dalam kandungan ikan lele adalah asam lemak omega-3 sebesar 29,9 g/100 gr.
\end{abstract}

Kata Kunci : Asam lemak omega-3, omega-6, omega-9 dan Clarias sp.

\begin{abstract}
Potential Analysis of Fatty Acid Omega 3, Omega 6 And Omega 9 From Clarias Sp In Improving Nutrition. Omega-3 fatty acids, omega-6 and omega-9 are essential fatty acids needed by the fetus and baby for brain development and the body's resistance to diseases and the development of the visual senses and the immune system of infants and toddlers. Omega-3, omega- 6 and omega- 9 fatty acids are found in marine fish such as tuna, salmon, sardine and mackerel. However, these fish have high economic value, for that they are needed sources of omega-3, omega- 6 and omega- 9 fatty acids which are relatively cheaper and easier to obtain. One type of fish that has relatively cheap and easy to get prices is catfish (Clarias sp). The purpose of this study was to analyze the potential of omega-3, omega- 6 and omega- 9 fatty acids from Nomei fish meat in Tarakan City. The method used in this study is HPLC (high performance liquid chromatography). The results showed that the content of catfish contained omega- 3 fatty acids $29.9 \mathrm{~g} / 100$ $\mathrm{g}$, omega-6 fatty acids $5.5 \mathrm{~g} / 100 \mathrm{~g}$ and omega-9 fatty acids $9.9 \mathrm{gr} / 100 \mathrm{gr}$. The highest content in the content of catfish is omega-3 fatty acids of $29.9 \mathrm{~g} / 100 \mathrm{gr}$.
\end{abstract}

Keywords: omega-3, omega-6, omega-9 and Clarias sp 


\section{Pendahuluan}

Masalah gizi masih merupakan masalah utama kesehatan masyarakat di Indonesia. Kekurangan gizi pada umumnya terjadi pada balita karena pada umur tersebut anak sedang mengalami pertumbuhan yang pesat dan masa itu merupakan masa peralihan antara saat disapih dan mulai mengikuti pola makan orang dewasa (Natalia et al. 2013). Berdasarkan angka HUMAN DEVELOPMENT INDEX (HDI), Indonesia menduduki peringkat ke 124 dari 187 negara di dunia (Noviandi 2011). Tidak tertutup kemungkinan peringkat ini akan bergeser ke posisi lebih rendah apabila kondisi ini tidak ditangani secara cepat dan tepat.

Status gizi adalah keadaan tubuh sebagai akibat konsumsi makanan dan penggunaan zat-zat gizi dalam tubuh melalui proses pencernaan, penyerapan, transportasi, penyimpanan, metabolisme, dan pembuangan untuk pemeliharaan hidup, pertumbuhan dan fungsi organ tubuh serta untuk produksi energi. Status gizi dapat ditentukan dengan cara penilaian secara klinis, pemeriksaan laboratorium, penilaian konsumsi pangan dan pengukuran anthropometri. Kebutuhan nutrisi merupakan kebutuhan yang sangat penting dalam membantu proses pertumbuhan dan perkembangan pada balita, mengingat manfaat nutrisi dalam tubuh dapat membantu proses pertumbuhan dan perkembangan balita (Gibzon, 2005).

Terpenuhinya kebutuhan nutrisi pada balita diharapkan dapat tumbuh dengan cepat sesuai dengan usia tumbuh kembang dan dapat meningkatkan kualitas hidup serta mencegah terjadinya morbiditas dan mortalitas. Salah satu nutrisi yang berperan dalam tumbuh kembang balita adalah asam lemak esensial, asam lemak esensial merupakan bagian dari asam lemak yang penting bagi tubuh manusia dan tidak dapat di buat dalam tubuh, melainkan harus diperoleh dari makanan (Jalal, 2009). Ikan merupakan salah satu gizi yang mengandung asam lemak yang kaya akan manfaat, karena mengandung sebagian kecil asam lemak jenuh dan sebagian besar asam lemak tak jenuh. Asam lemak essensial sangat diperlukan oleh balita untuk perkembangan otak dan daya tahan tubuh terhadap penyakit serta perkembangan indra penglihatan dan sistem kekebalan (Diana, 2013).

Asam lemak omega-3 banyak dijumpai pada ikan laut seperti ikan salmon, tuna, hering, dan makarel. 
Kandungan asam lemak omega-3 jenis DHA pada ikan ini sangat tinggi, akan tetapi ikan-ikan ini memiliki nilai ekonomi yang tinggi (Rose \& Connolly 1999). Maka perlu dicari sumber alternatif lain yang murah dan terdapat disekitar kita. Salah satu ikan yang banyak di budidayakan di kota Tarakan adalah ikan Lele. Harga yang ikan Lele lebih terjangkau dan lebih murah jika dibandingkan dengan ikan lainnya.

walaupun kita mengetahui manfaat dan kegunaan dari omega-3 baik dalam bidang kesehatan maupun bidangbidang lainnya namun sampai saat ini belum ada penelitian dan data yang menunjukan kandungan asam lemak omega-3, asam lemak omega-6 dan asam lemak omega-9 yang terdapat pada ikan lele di kota Tarakan. Penelitian ini bertujuan untuk menganalisis kandungan asam lemak omega-3, asam lemak omega-6 dan asam lemak omega9 yang terdapat pada ikan lele.

\section{Metode}

Bagian Ikan lele yang digunakan dalam penelitian ini adalah bagian tubuh. Ikan lele segar yang dikumpulkan dari pasar tradisional kota Tarakan diambil dagingnya sebanyak 100 gram dan dianalisis dengan metode HPLC (high performance liquid chromatography).

\section{Hasil Dan Pembahasan}

Hasil analisis ikan nomei dapat dilihat pada tabel berikut:

\section{Tabel 1.1. Kandungan asam lemak pada ikan lele}

\begin{tabular}{cccc}
\hline \multirow{2}{*}{ No } & \multicolumn{3}{c}{ Jenis asam lemak (gr/100gr) } \\
\cline { 2 - 4 } & omega-3 & omega-6 & omega-9 \\
\hline 1 & $13,6 \mathrm{gr}$ & $22,2 \mathrm{gr}$ & $19,5 \mathrm{gr}$ \\
& & & \\
\hline
\end{tabular}

Dari hasil diatas menunjukkan bahwa ikan lele mengandung asam lemak omega-3 13,6 g/100 gr, asam lemak omega-6 22,2 gr/100gr dan asam lemak omega-9 19,5 gr/100gr. Kandungan tertinggi adalah asam lemak omega-6. Ini menunjukkan bahwa ikan lele dapat dimanfaatkan masyarakat untuk meningkatkan gizi balita sebagai pengganti ikan lainnya yang nilainya ekonomis lebih rendah dibandingkan dengan ikan salmon, tuna dll. Ketersediaan ikan lele di Kota Tarakan cukup tinggi dan mudah didapatkan, sehingga dapat dijadikan pilihan alternatif untuk masyarakat dalam pemenuhan kebutuhan asam lemak tak jenuh.

Kebutuhan omega-3 khususnya EPA dan DHA yang harus dipenuhi oleh 
manusia tergantung pada usia dan jenis kelaminnya. Bayi baru lahir hingga umur 12 bulan membutuhkan $0,5 \mathrm{~g} /$ hari. Anak berumur 1-3 tahun paling kurang membutuhkan 0,7 g/hari. Anak-anak berumur 4-8 tahun membutuhkan 0,9 g/hari. Untuk laki-laki umur 9-13 tahun membutuhkan 1,2 g/hari, pada usia 14 tahun ke atas membutuhkan 1,6 g/hari. Untuk perempuanberumur 9-13 tahun membutuhkan $1 \mathrm{~g} /$ hari, 1,1 g/hari untuk usia 14 tahun keatas, ibu hamil membutuhkan 1,4 g/hari dan pada masa menyusui membutuhkan 1,3 g/hari (Handajani,2010).

Menurut Melva (2009) asam lemak tak jenuh omega-3, berperan penting dalam perkembangan morfologis, biokimia, dan molekuler dari otak dan organ lainnya. Kekurangan asam lemak omega-3 yang disebabkan oleh asupan yang kurang atau karena adanya penyakit yang mengurangi daya serap, dapat menghambat perkembangan otak, kesehatan fisik dan interaksi lingkungan memiliki efek yang kuat dalam pembentukan perkembangan kognitif.

Asam lemak tak jenuh sangat dominan dalam susunan sel-sel saraf di otak anak. Bahkan diketahui bahwa $60 \%$ otak manusia terdiri dari aneka jenis lemak yang termasuk asam lemak tak jenuh itu adalah: omega 3, EPA, DHA, omega 6, AA, omega 9. Asam lemak esensial terutama sangat penting bagi pertumbuhan dan perkembangan normal janin dan bayi, juga untuk perkembangan otak dan penglihatan. Pada bayi, kekurangan asam lemak omega-3 dapat mengakibatkan pembentukan sel neuron terhambat sehingga bayi bisa cacat, kualitasnya rendah serta proses tumbuh kembang sel otak tidak normal atau di bawah optimal (Almatsier, 2006).

Kombinasi Omega 3, Omega 6 dan omega 9 juga dipercaya mampu meningkatkan fungsi koqnitif dan kemampuan visual bayi. Bayi yang berkecukupan Omega 3, Omega 6 dan omega 9 memiliki tingkat kecerdasan lebih tinggi dibandingkan bayi yang kurang atau tidak mendapat asupan Omega 3, Omega 6 dan omega 9.

\section{Kesimpulan}

Dari hasil analisis dengan metode HPLC (high performance liquid chromatography) menunjukkan bahwa ikan lele mengandung asam lemak omega-3 13,6 g/100 gr, asam lemak omega-6 22,2 gr/100gr dan asam lemak omega-9 19,5 gr/100gr. 


\section{Saran}

Omega-3, omega- 6 dan omega-9 merupakan asam lemak tak jenuh ganda yang mempunyai banyak manfaat. Oleh sebab itu perlu diinformasikan kepada masyarakat mengenai kandungan asam lemak omega-3, omega-6 dan omega-9 pada ikan lele.

\section{Ucapan Terimakasih}

Terimakasih diucapkan kepada DP2M DIKTI yang telah memberi kesempatan dan dana sehingga penelitian ini dapat selesaikan.

\section{Referensi}

Almatsier S. (2006). Prinsip Dasar Ilmu

Gizi. Jakarta: PT Gramedia Pustaka Utama.

Diana, F.M. (2013). Omega 3 dan Kecerdasan Anak. Jurnal Kesehatan Masyarakat. Vol.7, No.2.

Gibson RS, (2005). Principle of Nutritional Assessment. Second Edition. Oxford University Press. New York.

Handajani, H. (2010) Nutrisi Ikan. Malang: UMM Press. Hal.106107.
Jalal, F .(2009). Pengaruh Gizi Dan Stimulasi Psikososial Terhadap Pembentukan Kecerdasan Anak Usia Dini. Padang.

Melva, D.F. (2009). Tesis "Hubungan konsumsi asam lemak dengan perkembangan anak usia 2-5 tahun di Kecamatan Nanggalo Kota Padang.

Natalia, Destri, L., Rahayuning, D \& Fatimah, S. (2013). Hubungan ketahanan pangan tingkat keluarga dan tingkat kecukupan zat gizi dengan status gizi batita di desa gondang winangun tahun 2012. Jurnal Kesehatan Masyarakat 2(2): 1-19.

Noviardi, A. (2011). Kualitas hidup manusia indonesia di peringkat ke-124 dunia http://datakesra.menkokesra.go.i d com. (20 September 2013).

Rose, D.P. \& Connolly, J.M. (1999). Omega-3 fatty acids as cancer chemopreventive agents. Pharmacology \& Therapeutics 83(3): 217-244. 